\title{
NOVÁ UČEBNICE SRBŠTINY
}

\author{
ELENA KREJČOVÁ \\ Masaryk University, Brno
}

\begin{abstract}
A NEW SERBIAN TEXTBOOK. A review of: Stefcheva, Rositsa. Serbian Language B1/B2. Sofia: St. Kliment Ohridski University Press, 2019, 276 pp., ISBN 978-954-07-4324-o [in Bulgarian / Serbian: Стефчева, Росица. Српски језик B1/В2. София: УИ Св. Климент Охридски, 2019, 276 стр.].

Keywords: Rositsa Stefcheva, Serbian for foreigners, foreign language textbook
\end{abstract}

V roce 2019 vydalo Univerzitní nakladatelství sv. Klimenta Ochridského v Sofii učebnici Српски језик B1/B2, jehož autorkou je dlouholetá vyučující srbštiny na Fakultě slovanských filologií Sofijské univerzity sv. Klimenta Ochridského dr. Rosica Stefčevová. Tato učebnice je zaměřena na osvojení jazykových znalostí a rozvoj komunikativních dovedností, které jsou v souladu s požadavky týkající se cizojazyčné výuky dle Společného evropského referenčního rámce pro úroveň znalosti jazyka $\mathrm{B} 1 / \mathrm{B}_{2}$.

Učebnice se skládá z šesti tematických celků (Годишња доба и временске прилике, Човек, Здравље и здрава храна, Путовања и рекреација, Образовање и посао, Уметност). Učebnice je založena na tzv. komunikativním přístupu, jehož cílem je rychlé osvojení komunikativních kompetencí, a současně studenty motivuje k samostatné a kreativní práci. Každý z těchto tematických celků má identickou strukturu, kde jsou komunikativní cíle (Комуникативни циљеви) а probíraný jazykový materiál (Језичко градиво) explicitně uvedeny v jednotlivých lekcích. Jazykový materiál je pak do struktury každé lekce zabudován do celků читање и разумевање, говорне вежбе, писање, граматика а превод. Rozčlenění jazykových a řečových aktivit do jednotlivých oddílů dává vyučujícímu volnost, aby mohl kombinovat jednotlivé komponenty výuky a přizpůsobit plán každé hodiny potřebám rozmanitých skupin studentů. Aktivity, které učebnice nabízí, pokrývají skoro všechny principy metodiky, kterou autorka zvolila při psaní své učebnice, jelikož obsahuje úkoly jak pro skupinovou, tak i pro samostatnou práci, což napomáhá zdokonalování už osvojených návyků, pokud jde o poslech a četbu s porozuměním, psaní a mluvení, čímž zdokonaluje i komunikativní kompetence studujících. Učebnice disponuje 
velmi bohatým ilustračním materiálem a řadou piktogramů, jejichž funkce je vysvětlena hned v předmluvě na str. 7. Oba prvky napomáhají nejen strukturování celého učebnicového korpusu, ale velmi důmyslně studentům umožňují rozpoznat jednotlivé typy úkolů a pracovat s nimi.

Samotné vybrané texty v učebnici odrážejí široké spektrum funkčních stylů současné srbštiny - od prostě sdělovacího přes administrativní až po umělecký styl. Každý text se věnuje aktuální problematice a jsou velmi blízké přirozenému jazykovému vyjadřování v samotném Srbsku (část textů představují úryvky z internetové komunikace). Kolokace a idiomy zakomponované do jednotlivých textů, odpovídají potřebám lingvokulturologického přístupu ve výuce cizího jazyka, který hraje zásadní roli v procesu formování komunikativních kompetencí a zároveň odpovídá i modernímu pohledu na lexikální zásobu, kterou chápeme nejen jako jednotlivá slova, ale i jako kolokace a více nebo méně ustálené výrazy, jejichž zvládnutí dává možnost rychleji ovládnout jazyk na požadované úrovni. Právě slovní zásoba v učebnici se obohacuje jednak pomocí překladových cvičení, jednak pomocí uvádění synonym, homonym, antonym, kolokací, použití určitých předložkových vazeb a konstrukcí v kontextu a samostatné práce se slovníkem. Autorka nezapomíná ani na frazeologické bohatství srbského jazyka (jak formou seznámení s frazémy a idiomy, tak i hledáním jejich překladových ekvivalentů), ani na mezijazykovou paronymii, která je mezi bulharštinou a srbštinou značná. U cvičení na překládání se autorka snaží o kontextualizaci osvojené slovní zásoby (rozpoznání vhodného lexikálního ekvivalentu nebo jazykové asymetrie), a tím pádem pokládá i základy překladatelských dovedností studentů.

Tvorba textu - at' už písemného nebo ústního, je přítomná ve cvičeních ke každé lekci. Výuka je plánovaně zaměřena na tvorbu, použití a práci s různými texty v různých diskurzech s cílem seznámit se i se stylistickými prostředky jednotlivých komunikačních aktů v standardních situacích (seznamovací inzeráty, pracovní inzeráty, motivační dopis, předpověd' počasí aj.). Studenti dostávají i další úkoly na tvorbu vlastních textů - verbalizace grafických vyobrazení, excerpce textu apod. Vyjádření vlastního názoru je realizováno prostřednictvím tvorby monologických (esej, e-mail) i dialogických (rozhovor, debata) útvarů a zároveň se klade důraz na formulaci a vyjádření argumentace zvlášt při diskutování nějakého problému. Psaní ve studovaném jazyce je orientováno na několik hlavních dovedností: deskripce, argumentace, tvorba textů informačního charakteru.

Cvičení v oddílu Говорне вежбе jsou zaměřeny právě na formování klíčových kompetencí: vedení konverzace, účast v diskusích, budování argumentačních technik a dovedností ve studovaném jazyce. Úkoly typu Замислите ситуацију... / Представете си ситуация... odrážejí současné trendy a požadavky, aby se student dostal do množství rozmanitých komunikativních situací simulujících autentické jazykové prostředí. Tímto je 
student přirozeně nucen použít jistá ustálená spojení nebo fráze, se kterými už byl seznámen v textu k lekci, a může si rovněž rozšiřit slovní zásobu dodatečnou samostatnou prací. Tímto je znovu zdůrazněn integrativní přístup autorky při koncipování jednotlivých lekcí. Systematicky představená srbská gramatika v oddíle Граматика vytváří předpoklad pro dobré ovládání znalostí a jejich kontroly vyučujícím. Při strukturování gramatického materiálu zde znovu nalezneme syntézu tradičních schémat a moderních komunikativních př́istupů.

Na konci učebnice nalezneme slovník, který shrnuje lexikální minimum ke každému z probíraných témat.

Na závěr můžeme říct, že učebnice je příkladem velmi kvalitní a zároveň moderní příručky, překrásně ilustrovaná, s mnoha grafikami, nezkostnatělou grafickou úpravou, použitím různých typů písem a barev jsou označena nap̌̌. ustálená spojení. Moderní co do struktury, svého obsahu a prezentace jazykového materiálu, který je srovnatelný s nejlepšími vzory pro didaktické publikace. Jako další přednost této učebnice musíme zmínit fakt, že je určena pro Slovany (především pro výuku praktické srbštiny na Sofijské univerzitě v rámci oboru Slovanská filologie s profilací srbština), je to v podstatě učebnice dělaná na míru bulharským studentům, není univerzální nebo cílená na anglojazyčné cizince, což dává možnost zaměřit se na specifické potřeby výuky konkrétního slovanského jazyka v bulharském prostředí s využitím znalostí a povědomí o společných mluvnických kategoriích bulharštiny a srbštiny a více se zaměřit na procvičování odlišností a problematických míst v rámci studia př́buzného jazyka. Práce s touto učebnicí pomůže nejen budovat lexikální a gramatické jazykové kompetence, ale též rozvíjet komunikativní dialogické i monologické dovednosti a budovat návyky správného a sofistikovaného vyjadřování v nejrůznějších komunikativních situacích. 